\title{
Effects of light, temperature, salinity, and maternal habitat on seed germination of Aeluropus lagopoides (Poaceae): an economically important halophyte of arid Arabian deserts
}

\author{
Arvind Bhatt, Sanjay Gairola, María Mercedes Carón, Andrea Santo, Valentina Murru, \\ Ali El-Keblawy, and Tamer Mahmoud
}

\begin{abstract}
In this study, salt tolerance during germination of Aeluropus lagopoides (L.) Trin. was tested using fresh seeds collected from three different maternal habitats under three thermoperiods and two light regimes. Additionally, we tested the ability of non-germinated seeds that had been exposed to different concentrations of $\mathrm{NaCl}$ to recover their germination in distilled water. The results showed a significant effect of seed source, temperature, and salinity, and some of their two- and three-way interactions on final germination and recovery percentage. The seeds from non-saline provenances had the highest percentages for germination (ca. $79 \%$ ) under the $35 / 25{ }^{\circ} \mathrm{C}$ temperature regime, whereas the lowest percentages for germination (ca. 21\%) was recorded for seeds from saline conditions under the $25 / 15^{\circ} \mathrm{C}$ treatment. Additionally, percent germination was significantly lower for the seeds incubated in the saline solutions $(100,200,400$, and $600 \mathrm{mmol} / \mathrm{L} \mathrm{NaCl})$ and germinated under colder conditions $\left(15 / 25^{\circ} \mathrm{C}\right.$ ), compared with the seeds incubated in non-saline solutions (control group, $0 \mathrm{mmol} / \mathrm{L} \mathrm{NaCl}$ ) and germinated under warmer conditions $\left(35 / 25{ }^{\circ} \mathrm{C}\right)$. The highest recovery percentage was recorded for seeds of the hypersaline habitat incubated at $35 / 25^{\circ} \mathrm{C}$. Thus, seeds maintained their viability despite experiencing a range of saline conditions and were able to germinate upon the arrival of suitable conditions, which can be an adaptation to its saline arid desert habitat.
\end{abstract}

Key words: Aeluropus lagopoides, germination recovery, maternal habitat, photoperiod, salinity, thermoperiod.

Résumé : Dans cette étude, la tolérance au sel lors de la germination de Aeluropus lagopoides (L.) Trin. a été testée sur des semences fraîches récoltées de trois habitats maternels différents, selon trois thermopériodes et deux régimes de luminosité. De plus, la capacité de semences non germées de récupérer leur potentiel de germination dans l'eau distillée après avoir été soumises à différentes concentrations de $\mathrm{NaCl}$ a été testée. Les résultats ont montré un effet significatif de la source des semences, de la température et de la salinité prises séparément, deux à deux ou toutes les trois, sur la germination et le pourcentage de récupération. Les semences provenant d'habitats non salins présentaient la germination la plus élevée (environ $79 \%$ à un régime de température de $35 / 25^{\circ} \mathrm{C}$, alors que la germination la plus faible (environ $21 \%$ ) était enregistrée chez les semences en conditions salines à des températures de $25 / 15^{\circ} \mathrm{C}$. Par ailleurs, la germination était significativement plus faible à partir d'une incubation dans une solution non saline - contrôle $(0 \mathrm{mmol} / \mathrm{L} \mathrm{NaCl})$ à des températures plus chaudes $\left(35 / 25^{\circ} \mathrm{C}\right)$ vers une incubation dans des solutions salines $(100,200,400$ et $600 \mathrm{mmol} / \mathrm{L} \mathrm{NaCl})$ à des températures plus froides $\left(15 / 25^{\circ} \mathrm{C}\right)$. Le pourcentage de récupération le plus élevé était enregistré chez les semences provenant d'un habitat hypersalin incubées à $35 / 25^{\circ} \mathrm{C}$. Ainsi, les semences maintenaient leur viabilité malgré le fait d'être exposées à un spectre de conditions salines et elles étaient capables de germer lors de l'arrivée de conditions adéquates, ce qui peut constituer une adaptation à leur habitat aride salin désertique. [Traduit par la Rédaction]

Mots-clés : Aeluropus lagopoides, récupération de la germination, habitat maternel, photopériode, salinité, thermopériode.

Received 11 May 2019. Accepted 27 October 2019.

A. Bhatt. Kuwait Institute for Scientific Research, P.O. Box 24885, Safat, 13109, Kuwait.

S. Gairola and T. Mahmoud. Sharjah Seed Bank and Herbarium, Sharjah Research Academy, P.O. Box 60999, Sharjah, UAE.

M.M. Carón. Instituto Multidisciplinario de Biología Vegetal (IMBIV), CONICET, Facultad de Ciencias Exactas, Físicas y Naturales,

Universidad Nacional de Córdoba, CC 495, 5000 Córdoba, Argentina.

A. Santo. Via dei gladioli 16 C, 09047 Selargius, Italy.

V. Murru. Dipartimento di Scienze della Vita e dell'Ambiente (DiSVA), Università degli Studi di Cagliari, viale S. Ignazio da Laconi 13, 09123 Cagliari, Italy.

A. El-Keblawy. Department of Applied Biology, College of Sciences, University of Sharjah, P.O. Box 27272, Sharjah, UAE.

Corresponding author: Sanjay Gairola (email: sgairola@sra.ae).

Copyright remains with the author(s) or their institution(s). Permission for reuse (free in most cases) can be obtained from RightsLink. 


\section{Introduction}

Desert plants generally experience extreme aridity, large fluctuations of water availability, and a relatively short growing season (Omar and Bhat 2008). For several desert plant species, the availability of light, temperature, and water are the main environmental factors influencing seed germination, plant growth, and survival (Weber 2009; Chen and Jiang 2010; El-Keblawy and Bhatt 2015; Bhatt et al. 2016a, 2016b, 2016c, 2016d, 2019). In particular, photoperiod contributes to determining when and where germination will take place (Fenner and Thompson 2005), although seeds from different plants show species-specific responses (e.g., some species require only light or darkness to germinate, whereas others germinate equally well in light and darkness (Baskin and Baskin 2014). Temperature plays an important role in seed germination timing and seedling establishment in desert plants (Baskin and Baskin 2014). Moreover, the interaction between light and temperature can modify the sensitivity of seeds to both factors (Sugahara and Takaki 2004; Baskin and Baskin 2014). However, it is known that different populations can show local adaptations in response to the spatial variability of environmental conditions, such as climatic and edaphic parameters (Leimu and Fischer 2008; Youssef 2009; Stanton-Geddes et al. 2012; Santo et al. 2017; El-Keblawy et al. 2018; Elnaggar et al. 2019). This could be controlled through factors prevailing during seed production and germination (Sambatti and Rice 2006).

Salinity levels in soil has been also defined as one of the most important variables influencing seed dormancy and germination of desert plants (Khan and Ungar 1996). Previous studies reported that the tolerance of halophytic grasses to salinity is species-specific and varies with the ecotype, habitat of provenance, and in relation to specific environmental factors (Gulzar et al. 2003b; Podda et al. 2017). Different studies have shown that the interactions between the parental plants and environmental conditions during seed development and maturation can affect seed dormancy and consequently the germination process (Fenner 1991b; Wulff 1995). Therefore, a better knowledge of the role of salinity on the maternal plant could be helpful in identifying suitable habitats that can produce seeds with low dormancy for future restoration programs. The inter-population variability in seed germination requirements (Murru et al. 2015; El-Keblawy et al. 2016, 2017, 2018; Murru et al. 2017) has a genetic base, but often is imputed to different phenotypic plasticity, frequently caused by the local environmental conditions during seed maturation (Gutterman 2000). In fact, both genotype and parental environmental conditions, such as maternal habitat and time of seed development on the mother plant (Wulff 1995; Gutterman 2000; El-Keblawy et al. 2017, 2018, 2019), are reported to play important roles in determining seed dormancy, germination characteristics, and germination requirements in several spe- cies (Fenner 1991a; Donohue and Schmitt 1998; Paolini et al. 1999; Galloway 2001a, 2001b).

Aeluropus lagopoides (L.) Trin. (Poaceae) is a perennial halophytic grass growing in northern Africa, the eastern Mediterranean region, the Middle East, the Arabian Peninsula, and central Asia. In the United Arab Emirates (UAE), it is locally common in coastal areas, sandy soils, and saline grounds. Aeluropus lagopoides has a wide occurrence on coastal zones all over the UAE, and it was also recorded from three inland wadis (Sharjah Seedbank \& Herbarium, unpublished data). The ability of A. lagopoides to grow in habitats that differ in salinity offers a good opportunity for studying the interactive effects of maternal habitat and salt exposure during germination. The UAE has a sub-tropical arid climate with sporadic and erratic rainfall, which mainly occurs from November to March, when the average temperatures are lowest. In fact, the studied species shows several adaptive features (e.g., vigorous seed production, slow vegetative propagation, strong network of roots, salt secreting habitus, and small leaves) necessary to survive in habitats subject to drought and under salt stress (Mohsenzadeh et al. 2006). Aeluropus lagopoides is of economic importance: it is utilized as a fodder in arid areas, and to stabilize soil/sand dunes (Gulzar et al. 2003a). Furthermore, this species has the potential to be used for landscaping the urban areas of desert regions (Phondani et al. 2016).

The effects of temperature, light, and salinity on the seed germination of A. lagopoides has been investigated previously (Gulzar and Khan 2001; Khan and Gulzar 2003b; Gulzar et al. 2003a), but the different studies were conducted on seeds from a single population/habitat and did not evaluate the inter-population variability. Furthermore, the influence of saline environments experienced by the mother plant on the germination of offspring seeds of A. lagopoides has not yet been studied. However, it is known that seeds from different habitats where the species is surviving may have different adaptation strategies to specific environmental conditions during germination. Therefore, we investigated the seed germination ecophysiology of A. lagopoides from different habitats of the arid deserts of UAE. The specific goals of this research were to test the germination response, salinity tolerance, and germination recovery to temperature and photoperiod, of seeds collected from three different maternal habitats (hyper-saline, saline, and nonsaline soils).

\section{Materials and methods}

Seed collection and storage

Mature caryopses (hereinafter referred to as seeds) of A. lagopoides were collected at the time of natural dispersal (May-July) from three populations experiencing different soil salinity levels (see Table 1). The tested populations were $\mathrm{T}$ from hyper-saline (Kalba: $25^{\circ} 0^{\prime} 18.02^{\prime \prime} \mathrm{N}$; $56^{\circ} 20^{\prime} 55.81^{\prime \prime} \mathrm{E}$ ), saline (Al Mergab: $25^{\circ} 23^{\prime} 30.40^{\prime \prime} \mathrm{N} ; 5^{\circ} 25^{\prime} 47.44^{\prime \prime} \mathrm{E}$ ), and 
Table 1. Habitat characteristics and mean seed mass of Aeluropus lagopoides.

\begin{tabular}{|c|c|c|c|c|}
\hline Habitat & Associated species & $\begin{array}{l}\text { Mean seed } \\
\text { mass }(\mathrm{mg} \pm \mathrm{SD})\end{array}$ & Soil pH & $\begin{array}{l}\text { Soil electrical } \\
\text { conductivity }(\mathrm{mS} / \mathrm{cm})\end{array}$ \\
\hline Hyper-saline (Kalba) & $\begin{array}{l}\text { Suaeda aegyptiaca } \\
\text { Heliotropium kotschyi } \\
\text { Launaea capitata } \\
\text { Salsola drummondii } \\
\text { Zygophyllum qatarens }\end{array}$ & $15.1 \pm 0.40$ & 8.12 & 5.50 \\
\hline Saline (Al Mergab) & $\begin{array}{l}\text { Sporobolus spicatus } \\
\text { Sesuvium verrucosum } \\
\text { Cyperus arenarius } \\
\text { Phragmites australis } \\
\text { Suaeda vermiculata }\end{array}$ & $8.6 \pm 0.10$ & 8.37 & 3.01 \\
\hline Non-saline (Al Hamriya) & $\begin{array}{l}\text { Crotalaria persica } \\
\text { Lotus garcinii } \\
\text { Heliotropium kotschyi }\end{array}$ & $14.2 \pm 0.07$ & 8.61 & 1.56 \\
\hline
\end{tabular}

non-saline soils (Al Hamriyah: $25^{\circ} 29^{\prime} 8.90^{\prime \prime} \mathrm{N}$; 55 $30^{\prime} 8.14^{\prime \prime} \mathrm{E}$ ) in the Sharjah Emirate, UAE (Table 1). In each population, the seeds were randomly collected from 150-200 plants, cleaned, and pooled to represent the local genetic diversity. After collection, the seeds were stored at room temperature $\left(20 \pm 2{ }^{\circ} \mathrm{C}\right)$ for three weeks until the beginning of the experiments. The mean seed mass was determined for seeds lots from each habitat by weighing three replicates each of 100 seeds (Table 1 ).

A soil analysis was conducted to identify the $\mathrm{pH}$ and salinity of the soil from the three study sites. Five soil samples were collected randomly from each site at a depth of about $15 \mathrm{~cm}$ (excluding the surface crust). These samples were then pooled together to form one composite sample, air-dried, and thoroughly mixed for the analysis. Soil-deionized water extracts $(1: 5 w / v)$ were prepared in triplicate to measure electrical conductivity (EC) and $\mathrm{pH}$. Conical flasks with soil suspensions were swirled in an orbital shaker for $15 \mathrm{~min}$, and then allowed to settle for $5 \mathrm{~min}$. After the prescribed settling time, $\mathrm{EC}$ and $\mathrm{pH}$ were determined using a Hanna soil pH/EC/TDS tester (model HI98130; Hanna Instruments).

\section{Effect of light, temperature, and provenance on seed germination}

To investigate the effect of light and temperature on germination, seeds from each tested habitat were sown with distilled water at three daily temperature regimes of $25 / 15,30 / 20$, and $35 / 25{ }^{\circ} \mathrm{C}$ in both continuous darkness and with a $12 \mathrm{~h}$ light : $12 \mathrm{~h}$ darkness regime. The incubation temperatures were set to simulate the temperature fluctuations in the natural habitats during the seasons of seed germination. For the dark treatment, the Petri dishes were wrapped in two layers of aluminum foil to prevent any exposure to light. The seeds were germinated in tight-fitting Petri dishes $(9 \mathrm{~cm}$ diameter) containing three disks of Whatman No. 1 filter paper moistened with $10 \mathrm{~mL}$ of distilled water. Three replicates, each with 25 seeds per habitat, were used for each treat- ment. The seeds were considered to be germinated when the radicle emerged ( $\geq 2 \mathrm{~mm}$ ). The germinated seeds were counted and removed daily for 30 days. The seeds incubated in the dark were only checked at the end of the total germination trial (30 days).

At the end of the germination tests, all of the ungerminated seeds were punctured and then categorized as either mouldy or healthy. The mouldy seeds were considered dead. However, the non-mouldy seeds were considered as either dead or viable. The viability of these seeds was tested after soaking them in $1 \%$ tetrazolium chloride solution for $24 \mathrm{~h}$, and then the cut seeds were examined under a binocular microscope (data not shown).

\section{Effect of salinity, temperature, and provenance on seed germination}

To determine salinity tolerance during germination, three replicates of 25 seeds per seed lot from each habitat were sown at one of five salinity levels $(0,100,200,400$, or $600 \mathrm{mmol} / \mathrm{L} \mathrm{NaCl}$ ) using the same temperature treatments mentioned above. The seeds were germinated in Petri dishes ( $9 \mathrm{~cm}$ diameter) on a layer of Whatman No. 1 filter paper, and moistened with $10 \mathrm{~mL}$ of different concentrations of $\mathrm{NaCl}$. The Petri dishes were sealed with plastic film to prevent evaporation. The germinated seeds were counted and removed from the dishes daily for 30 days (end of the experiment). All of the seeds that failed to germinate under different $\mathrm{NaCl}$ concentrations were removed at the end of the trial, rinsed three times in distilled water, and then incubated in distilled water for 15 days. Recovery percentages (RPs) were evaluated for seeds that failed to germinate in the different salt solutions.

\section{Data analyses}

Mean germination time (MGT) was calculated using the formula: $\mathrm{MGT}=\Sigma D N / \Sigma N$; where $D$ is the number of days counted from the date of sowing and $N$ is the number of seeds germinated on day D (Ellis and Roberts 1981). 
Table 2. Effect of provenance, light, temperature, and their interactions on final germination percentage of Aeluropus lagopoides seeds.

\begin{tabular}{lll}
\hline Predictor & df & $P\left(>\chi^{2}\right)$ \\
\hline Provenance $(\mathrm{P})$ & 2 & $6.304 \mathrm{e}-11^{* * *}$ \\
Light $(\mathrm{L})$ & 1 & $0.3713 \mathrm{~ns}$ \\
Temperature $(\mathrm{T})$ & 2 & $<2.2 \mathrm{e}-16^{* * *}$ \\
$\mathrm{~L} \times \mathrm{P}$ & 2 & $0.1987438 \mathrm{~ns}$ \\
$\mathrm{~L} \times \mathrm{T}$ & 2 & $3.839 \mathrm{e}-11^{* * *}$ \\
$\mathrm{P} \times \mathrm{T}$ & 4 & $0.0001613^{* * *}$ \\
$\mathrm{P} \times \mathrm{L} \times \mathrm{T}$ & 4 & $0.001985^{* *}$ \\
\hline
\end{tabular}

Note: ns, not significant; **, $P<0.01$, ${ }^{* * *}, P<0.001$, according to the likelihood ratio test.

Recovery percentage (RP) was calculated using the formula: $\mathrm{RP}=[(a-b) /(c-b)] \times 100$, where $a$ is the total number of seeds germinated in the saline solutions plus those that recovered and germinated in distilled water; $b$ is the total number of seeds germinated in saline solutions; and $c$ is the total number of seeds. The germination of seeds incubated with distilled water recorded under different light and temperature conditions was analyzed as a function of the seeds' provenance and incubation conditions (i.e., light and temperature) using a generalized linear model (GLM) with binomial error structures. Additionally, seed germination, mean germination time (MGT), and the recovery percentage (RP) of seeds incubated under different temperatures and saline solutions were analyzed as a function of the provenance, salinity level, and temperature, using GLM with binomial (germination) and Gaussian error structures (MGT and RP) with the 'nlme' package in $\mathrm{R}$ (version 3.1.2; R Core Team 2014). RP data were arcsine square-root transformed to achieve normality and homogeneity of variance prior to analysis. For all of the analyzed variables, first the full model was fitted with all the factors and interactions included, after which, the models were simplified, first by dropping the least significant interaction, and then the least significant individual variable at each step. The comparison between models was based on the likelihood ratio test (LRT) for the binomial data, and on the scaled deviance for the Gaussian data, until all of the remaining terms were significant (Zuur et al. 2009).

\section{Results}

\section{Effect of provenance, light, and temperature on seed} germination

The final germination of A. lagopoides seeds varied according to the seeds' provenance and the incubation temperature (Table 2; Supplementary data, Table S1 ${ }^{1}$ ). Temperature significantly influenced percent germination, and a decrease in percent germination from the warmer $\left(25 / 35^{\circ} \mathrm{C}\right)$ to the colder $\left(15 / 25^{\circ} \mathrm{C}\right)$ conditions was recorded. Additionally, the three-way and two-way inter-
Fig. 1. Germination percentages as a function of provenance, light, and temperature conditions. "Cycles of light" indicates the $12 \mathrm{~h}$ light : $12 \mathrm{~h}$ dark photoperiod. Error bars indicate standard error (SE).

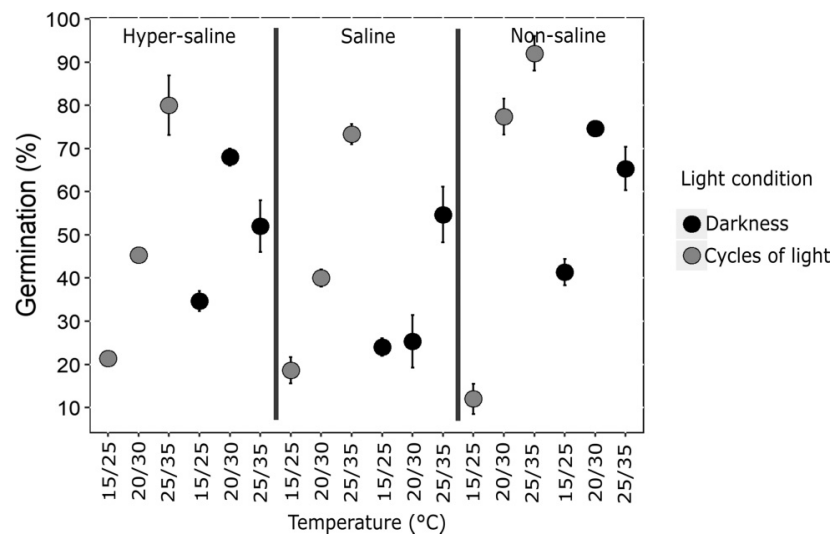

actions between and among factors influenced seed germination for this species (Table 2; Fig. 1). The seeds from F1 non-saline provenances showed a high germination percentage (ca. $79 \%$ ) under the $35 / 25^{\circ} \mathrm{C}$ temperature regime, and the lowest germination percentage (ca. 21\%) was recorded in seeds from saline conditions germinated under the $25 / 15^{\circ} \mathrm{C}$ treatment (the interaction of provenance $\times$ temperature was significant; Fig. 1). The interaction between light conditions and temperature was also significant, with the germination percentage decreasing from $81.8 \%$ at $35 / 25{ }^{\circ} \mathrm{C}$ with cycles of light, to $17.3 \%$ at $25 / 15{ }^{\circ} \mathrm{C}$ in the dark or with cycles of light, respectively.

Effects of provenance, salinity, and temperature on seed germination

All of the main factors (i.e., provenance, salinity, and temperature) significantly affected germination (Table 3; т3 Supplementary data, Table $S 2^{1}$ ). The germination percentage increased from the cooler to the warmer incubation temperatures, and from the highest salinity level $(600 \mathrm{mmol} / \mathrm{L} \mathrm{NaCl})$ to the control level $(0 \mathrm{mmol} / \mathrm{L} \mathrm{NaCl})$.

The interaction between provenance and salinity was significant $(P<0.001$; Table 3$)$. Seeds from the hypersaline habitat did not germinate under the different levels of salinity tested, but seeds from the non-saline or saline habitats attained some germination under saline conditions. Additionally, the interaction between provenance and temperature was significant $(P<0.01$; Table 3$)$. Considering all of the salinity treatments together, the highest germination (18.5\%) was recorded in seeds from non-saline provenances incubated at $35 / 25{ }^{\circ} \mathrm{C}$, while the lowest germination $(4.8 \%)$ was recorded for seeds from the hyper-saline provenances incubated at $25 / 15{ }^{\circ} \mathrm{C}$ (Fig. 2). The interaction between temperature and salinity $\mathbf{F 2}$ was significant, indicating that salinity tolerance during germination depends on the incubation temperature.

${ }^{1}$ Supplementary data are available with the article through the journal Web site at http://nrcresearchpress.com/doi/suppl/10.1139/cjb2019-0096. 
Table 3. Effects of provenance (P), salinity levels (S), temperature $(\mathrm{T})$ and their interactions on final germination, mean germination time (MGT) and germination recovery of Aeluropus lagopoides seeds.

\begin{tabular}{|c|c|c|c|c|c|c|}
\hline \multirow[b]{2}{*}{ Predictor } & \multicolumn{2}{|c|}{ Final germination } & \multicolumn{2}{|c|}{ MGT } & \multicolumn{2}{|c|}{ Germination recovery } \\
\hline & df & $P\left(>\chi^{2}\right)$ & df & $P\left(>\chi^{2}\right)$ & df & $P\left(>\chi^{2}\right)$ \\
\hline Provenance $(\mathrm{P})$ & 2 & $4.667 \mathrm{e}-10^{* * *}$ & 2 & $0.4791 \mathrm{~ns}$ & 2 & $0.02^{*}$ \\
\hline Salinity (S) & 1 & $<2.2 \mathrm{e}-16^{* * *}$ & 1 & $0.0002088^{* * *}$ & 1 & $4.249 \mathrm{e}-11^{* * *}$ \\
\hline Temperature (T) & 2 & $<2.2 \mathrm{e}-16^{* * * *}$ & 2 & $1.73 \mathrm{e}-05^{* * *}$ & 2 & $4.517 \mathrm{e}-07^{* * *}$ \\
\hline $\mathrm{P} \times \mathrm{T}$ & 4 & $0.006795^{* *}$ & 4 & $0.003958^{* *}$ & 4 & $0.001495^{* *}$ \\
\hline $\mathrm{T} \times \mathrm{S}$ & 2 & $1.183 \mathrm{e}-05^{* * *}$ & 2 & $0.195831 \mathrm{~ns}$ & 2 & $0.0863702 \mathrm{~ns}$ \\
\hline $\mathrm{P} \times \mathrm{S}$ & 2 & $1.701 \mathrm{e}-15^{* * *}$ & 2 & $0.036453^{*}$ & 2 & $0.017971^{*}$ \\
\hline $\mathrm{P} \times \mathrm{T} \times \mathrm{S}$ & 4 & $5.6 e-15^{* * *}$ & 4 & $0.2333 \mathrm{~ns}$ & 4 & $0.1284 \mathrm{~ns}$ \\
\hline
\end{tabular}

Note: ns, not significant; *, $P, 0.05$; **, $P<0.01$; and ${ }^{* * *}, P<0.001$, according to the comparison of scaled deviation.

Fig. 2. Seed germination as a function of the provenance, salinity, and temperature of incubation.

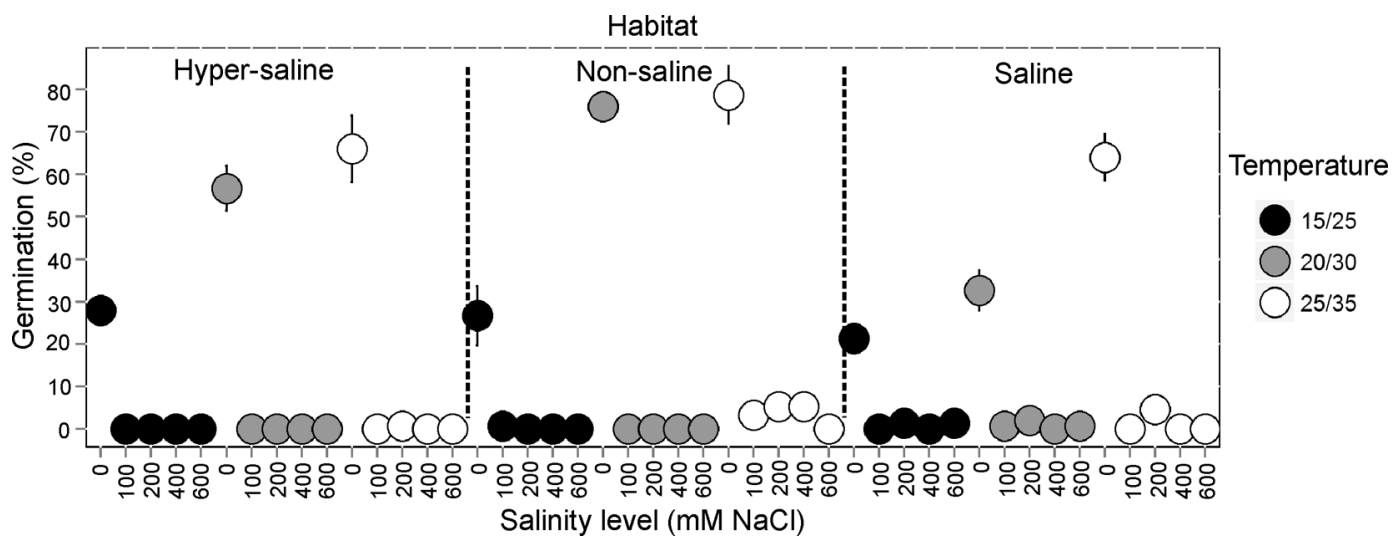

The germination percentage was greater for seeds incubated under non-saline conditions (control, $0 \mathrm{mmol} / \mathrm{L}$ $\mathrm{NaCl})$ and with warmer temperatures $\left(35 / 25^{\circ} \mathrm{C}\right)$ than for the seeds incubated in saline solutions $(100,200,400$, and $600 \mathrm{mmol} / \mathrm{L} \mathrm{NaCl}$ ) and with colder temperatures (25/ $15{ }^{\circ} \mathrm{C}$ ) (Table 2).

\section{Mean germination time}

The MGT was independent of the seeds' provenance, but varied as a function of the salinity and temperature (Table 3). However, owing to the strong negative influence of salinity on germination, the results for MGT as function of salinity should be considered with caution. The MGT decreased (see the Supplementary data, Table S3 ${ }^{1}$ ) with increasing temperatures (i.e., seeds incubated under warmer conditions germinated faster than seeds germinated under colder conditions; Fig. 3). The interactions between salinity and both provenance and temperature were significant, indicating that the germination speed depends on both the salinity of the maternal environment and temperature of seed incubation (Table 3).

\section{Germination recovery}

RPs varied as a function of all the main factors (provenance, temperature, and salinity) (Table 3; Supplementary data, Table S4 ${ }^{1}$ ). RPs were also influenced by the two-way interactions between habitat and temperature and temperature and salinity, whereas the interaction between habitat and salinity was not significant (Table 3). The highest RP was recorded for seeds from the hyper- saline habitat incubated at $35 / 25^{\circ} \mathrm{C}$, and the lowest was for seeds from the hyper-saline habitat incubated at $25 / 15^{\circ} \mathrm{C}$ as well as for seeds from the saline habitat incubated at $25 / 15{ }^{\circ} \mathrm{C}$ (Fig. 4; Supplementary data, Table S4 ${ }^{1}$ ). F4 In addition, the highest value for RP was recorded for seeds germinated in the lower salinity solution $(100 \mathrm{mmol} / \mathrm{L} \mathrm{NaCl})$ and with higher temperatures $35 / 25^{\circ} \mathrm{C}$, whereas the lowest germination RP was recorded for seeds incubated at the highest salinity $(600 \mathrm{mmol} / \mathrm{L} \mathrm{NaCl})$ and with lower temperatures $25 / 15{ }^{\circ} \mathrm{C}$ (Fig. 5).Viability testing showed $\mathrm{F5}$ that most of the seeds were viable: however, they did not recover germination after being incubated at the highest salinity with the lowest temperature.

\section{Discussion}

Environmental conditions at the maternal source showed a strong influence on seed germination requirements. This probably can be linked to differences in soil mineral and nutrient concentrations, temperature, and water availability. In this study, freshly matured seeds of A. lagopoides showed low levels of innate dormancy; final germination reached high levels (up to $80 \%$ in distilled water), especially at high temperatures. However, the seeds entered a salinity-induced dormancy, even at low concentrations of salinity (i.e., $100 \mathrm{mmol} / \mathrm{L} \mathrm{NaCl}$ ). Similar results have been reported earlier for Aeluropus lagopoides and other desert grasses such as Sporobolus arabicus, Cenchrus ciliaris, Dichanthium annulatum, Halopyrum mucronatum, Pennisetum divisum, Lasiurus scindicus, and Urochondra setulosa 
Fig. 3. Average germination of seeds from the three selected habitats at each time point along the experiment, and as a function of the salinity concentrations (top panel), and the temperatures of incubation (bottom panel). Error bars are not shown to avoid overlapping.

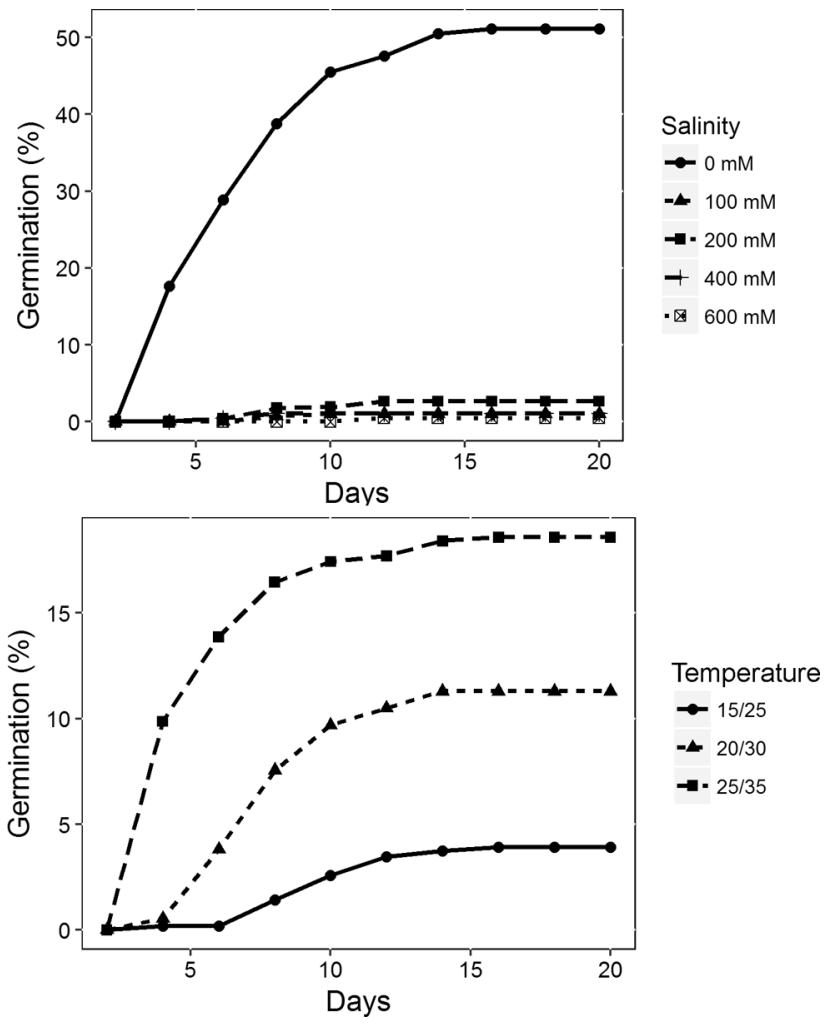

Fig. 4. Germination recovery as a function of provenance and temperature.

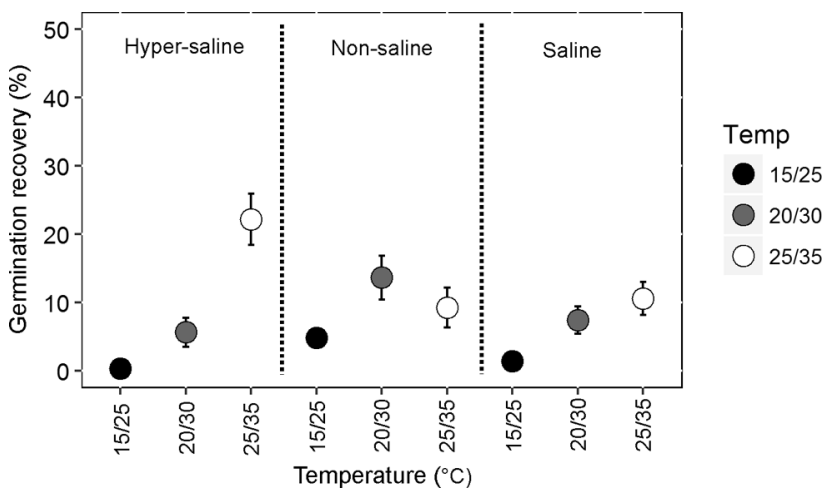

(Khan and Gulzar 2003a; El-Keblawy 2006; El-Keblawy et al. 2011). Seeds entering an enforced dormancy at low concentrations of $\mathrm{NaCl}$ indicates that the plants postpone germination until heavy rainfall reduces the soil salinity to less than $100 \mathrm{mmol} / \mathrm{L} \mathrm{NaCl}$. This ensures that seedlings will emerge at the proper time of the year and in the presence of enough water to ensure successful seedling establishment and survival (El-Keblawy et al. 2018; Elnaggar et al. 2019). In the absence of rainfall, A. lagopoides seeds may enter the soil seed bank and stay dormant (Bhatt and Pérez-García 2016). It has been reported that A. lagopoides
Fig. 5. Germination recovery as a function of temperature and salinity.

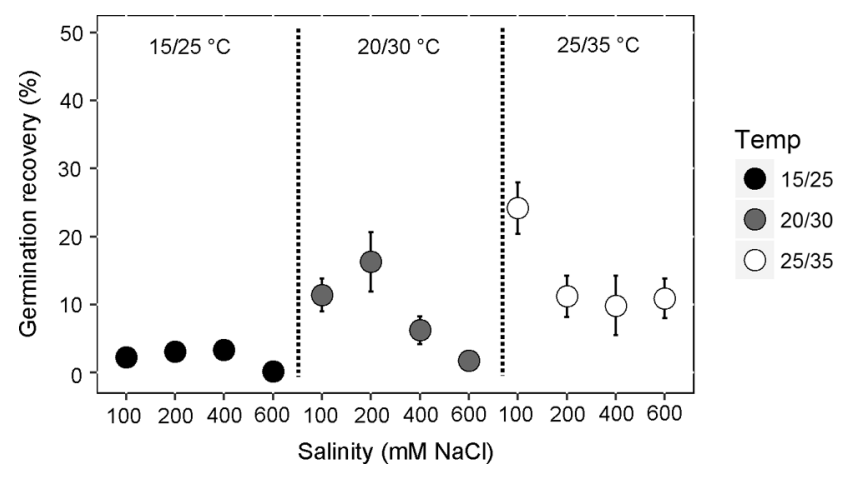

maintains a transient seed bank in coastal salt marshes of the subtropical climate of Pakistan (Khan and Gul 1999). Differences in the germination of seeds from different habitat types has been linked to the combined influence of genetic and environmental factors for several indifferent halophytes (i.e., grow well in both saline and non-salty soils) (El-Keblawy et al. 2016, 2017, 2018).

In this study, provenance significantly affected final germination in both the distilled water and the saline solutions. Interestingly, significantly more seeds from the non-saline habitat germinated in distilled water, both at $30 / 20^{\circ} \mathrm{C}$ and at $35 / 25^{\circ} \mathrm{C}$, compared with the seeds from the saline and the hyper-saline habitats that were incubated under colder conditions. In addition, seeds from the non-saline habitat attained some germination in 100-400 mmol/L NaCl, but those from plants of saline and hyper-saline habitats showed almost no germination in the salt solutions. El-Keblawy et al. (2018) interpreted the low germination of seeds from plants of the saline habitats to the accumulation of high levels of abscisic acid (ABA) in the plants from these habitats under salinity stress. Such high levels of ABA could probably have carried over to the seeds and affected their final germination and tolerance to salinity stress (Boyko and Kovalchuk 2011; Migicovsky et al. 2014). Several reports have shown that high levels of ABA, or a lowered ratio of gibberellic acid (GA) to ABA, could induce dormancy (Kucera et al. 2005). In seeds from plants of the non-salty habitats, however, low levels of ABA and high levels of GA (i.e., higher GA:ABA ratio) are expected (El-Keblawy et al. 2018). The assessment of the different phytohormones in seeds from plants growing in habitats that differ in salinity levels is very important to understand their role in germination regulation and controlling salinity stress.

The light requirement for germination varied with the tested temperature regimes, indicating that seeds respond to particular combinations of light and temperature to germinate, as reported for several other species (Pons 1992; El-Keblawy and Al-Rawai 2005). Buried seeds (dark conditions simulated here) can germinate better at high $\left(25 / 35{ }^{\circ} \mathrm{C}\right)$ or moderate $\left(20 / 30{ }^{\circ} \mathrm{C}\right)$ temperature re- 
gimes when incubated in distilled water. These data suggest that germination will occur once rain events leach the salt out of the soil, which usually occurs between December to March in the study area. At this time of year, the average monthly temperature is around 20$27.9^{\circ} \mathrm{C}$, and the chances of rainfall are high (Böer 1997; Islam et al. 2009). However, if A. lagopoides seeds remain at the surface, where they face higher fluctuations in light and day/night temperatures, they would have their light and the higher temperature requirements (El-Keblawy and Al-Shamsi 2008; El-Keblawy et al. 2017). However, it is important to consider that the seeds of A. lagopoides are small and contain limited amounts of storage reserves for early development. Therefore, when seeds germinate deeper into the soil their reserves may be exhausted before the seedlings emerge (ISTA 2003).

Our results showed that seeds collected from habitats with different salinity germinated significantly better at higher $\left(35 / 25^{\circ} \mathrm{C}\right)$ than at lower temperatures $\left(25 / 15{ }^{\circ} \mathrm{C}\right)$. Therefore, the fluctuating temperatures between $35 / 25^{\circ} \mathrm{C}$ can be considered as the most optimal for successful germination of this species, regardless of the provenance. The higher germination under warmer conditions might be linked to some eco-physiological processes such as increasing membrane permeability, as well as the activity of membrane-bound proteins and cytosol enzymes, which increase the ability of seeds to germinate (Bewley and Black 1994). The ability of seeds of A. lagopoides to germinate at high temperatures indicates that they can germinate if rainfall events take place by the end of the growing seasons (i.e., March-May). Germinated seedlings could be affected by the high temperatures of summer that can reach up to $50^{\circ} \mathrm{C}$ on some days. Therefore, seedlings and plants may die unless they develop proper mechanisms to cope with high salinity of soils, high temperatures, and water scarcity. Naz et al. (2009) investigated structural and functional modifications in three differently adapted ecotypes of A. lagopoides and concluded that long-term exposure of these ecotypes to their specific habitats imposed changes in their genetic makeup, which ensure their successful survival in their respective habitats.

Seed germination is a crucial stage in life history of a plant, and coastal plants are expected to exhibit some tolerance to salinity (Woodell 1985). Variations in salinity tolerance during germination might be attributed to other environmental factors characterizing the maternal habitat, such as changing in soil composition, local rainfall pattern, etc. (Baskin and Baskin 2014; Bhatt et al. 2016a, 2016e; El-Keblawy et al. 2016, 2017). For example, previous studies have shown that soil texture and soil depth can influence the moisture regime in arid environments with episodic rainfall, which could affect seed development that in turn affects seed dormancy and germination response to a particular soil water stress (Fenner 1991b; Refka et al. 2015; Bhatt and Santo 2017,
2018). Therefore, we assumed that maternal habitat plays an important role in determining the salinity tolerance of A. lagopoides seeds, but such results should be considered cautiously because this was not true for seeds from hyper-saline habitats. Similar to our findings, Gulzar et al. (2003b) reported that the salinity tolerance of halophytic grasses varies with the ecotype, species, habitat, and other environmental factors. Therefore more environmental aspects should be included to determine more clearly which factor is the most important for seed germination and salinity tolerance of the studies species.

Lower salinities and higher temperatures decreased the MGT in A. lagopoides seeds, indicating that the increase in salinity would delay germination, which is probably linked to a prevention of water absorption that is essential for seed imbibition and starting the germination process. However, these results should be considered with caution due to the overall low germination reported under the different saline solutions. Moreover, to verify this aspect it would be important to test the effect of osmolarity with polythylene glycol. Faster germination in low salinity, irrespective of habitat type, might be an adaptation to establish seedlings immediately after the rainfall period. Similar results have been reported for A. lagopoides by Gulzar and Khan (2001) and for Phragmites australis by Xianzhao et al. (2013).

Aeluropus lagopoides seeds showed variation in RP when transferred from saline solutions to distilled water. Seeds from the hyper-saline habitats showed the highest recovery rate at higher temperatures compared with seeds collected from the other two habitats under the same temperature conditions. These finding concur with the study of Gulzar and Khan (2001), who reported that the germination recovery of A. lagopoides was greater at higher temperatures.

In conclusion, our results showed that seeds of A. lagopoides are sensitive to salinity, and therefore seed germination in nature will be difficult unless natural soil salinity is reduced by rainfall. This kind of study, although not common, can provide useful information for environmental restoration activities, because it allowed us to highlight the different ranges of environmental conditions that seeds of species from different habitats/ source can tolerate, increasing the probability of in situ germination success.

\section{References}

Baskin, C.C., and Baskin, J.M. 2014. Seeds: ecology, biogeography, and evolution of dormancy and germination. 2nd ed. Academic Press, San Diego, Calif.

Bewley, J.D., and Black, M. (Editors). 1994. Seeds: germination, structure, and composition. In Seeds: physiology of development and germination. Plenum Press, New York. pp. 1-33.

Bhatt, A., and Pérez-García, F. 2016. Seed dormancy of Ochradenus baccatus (Resedaceae), a shrubby species from Arabian Desert regions. Rev. Biol. Trop. 64(3): 965-974. doi:10.15517/rbt.v64i3. 19824. PMID:29461763.

Bhatt, A., and Santo, A. 2017. Effects of photoperiod, thermoperiod, and salt stress on Gymnocarpos decandrus seeds: potential 
implications in restoration ecology activities. Botany, 95(11): 1093-1098. doi:10.1139/cjb-2017-0086.

Bhatt, A., and Santo, A. 2018. Does perianth colour affect the seed germination of two desert shrubs under different storage periods and conditions? Nord. J. Bot. 36(6): njb-01593. doi:10.1111/njb.01593.

Bhatt, A., Santo, A., and Gallacher, D. 2016a. Seed mucilage effect on water uptake and germination in five species from the hyper-arid Arabian desert. J. Arid Environ. 128: 73-79. doi:10.1016/j.jaridenv.2016.01.008.

Bhatt, A., Gairola, S., and El-Keblawy, A. 2016b. Seed colour affects light and temperature requirements during germination in two species of Lotus species (Fabaceae) of the Arabian subtropical deserts. Rev. Biol. Trop. 64(2): 483-492. doi:10. 15517/rbt.v64i2.18575. PMID:29451749.

Bhatt, A., Pérez-García, F., and Phondani, P.C. 2016c. Foliage colour influence on seed germination of Bienertia cycloptera in Arabian deserts. Nord. J. Bot. 34: 428-434. doi:10.1111/njb. 00974.

Bhatt, A., Pérez-García, F., Carón, M.M., and Gallacher, D. 2016d. Germination response of Salsola schweinfurthii (Chenopodiaceae) to salinity and winged perianth removal. Seed Sci. Technol. 44: 1-7. doi:10.15258/sst.2016.44.1.04.

Bhatt, A., Phondani, P.C., Phartyal, S.S., Santo, A., and Gallacher, D. 2016e. Influence of aerial seed banks on germination response in three desert plant species. J. Plant Ecol. 10(6): 994-100. doi:10.1093/jpe/rtw113.

Bhatt, A., Bhat, N.R., Suleiman, M.K., and Santo, A. 2019. Effects of storage, mucilage presence, photoperiod, thermoperiod and salinity on germination of Farsetia aegyptia Turra (Brassicaceae) seeds: implications for restoration and seed banks in Arabian Desert. Plant Biosyst. 153: 280-287. doi:10.1080/ 11263504.2018.1473524.

Böer, B. 1997. An introduction to the climate of the United Arab Emirates. J. Arid Environ. 35(1): 3-16. doi:10.1006/jare.1996. 0162.

Boyko, A., and Kovalchuk, I. 2011. Genome instability and epigenetic modification-heritable responses to environmental stress? Curr. Opin. Plant Biol. 14: 260-266. doi:10.1016/j.pbi. 2011.03.003. PMID:21440490.

Chen, H., and Jiang, J.-G. 2010. Osmotic adjustment and plant adaptation to environmental changes related to drought and salinity. Environ. Rev. 18: 309-319. doi:10.1139/A10-014.

Donohue, K., and Schmitt, J. 1998. Maternal environmental effects in plants: adaptive plasticity? In Maternal effects as adaptations. Edited by T.A. Mousseau and C.W. Fox. Oxford University Press, Oxford, England. pp. 137-158.

El-Keblawy, A. 2006. Overcoming innate dormancy and determination of germination requirements of economic salt tolerant native plants of the UAE. In Proceedings of the 7th annual Conference for Research funded by UAE University. Al-Ain, United Arab Emirates. pp. SCI 97-107.

El-Keblawy, A., and Al-Rawai, A. 2005. Effects of salinity, temperature and light on germination of invasive Prosopis juliflora (Sw.) D.C. J. Arid Environ. 61(4): 555-565. doi:10.1016/j.jaridenv. 2004.10.007.

El-Keblawy, A., and Al-Shamsi, N. 2008. Salinity, temperature and light affect seed germination of Haloxylon salicornicum, a common perennial shrub of the Arabian deserts. Seed Sci. Technol. 36: 679-688. doi:10.15258/sst.2008.36.3.17.

El-Keblawy, A., and Bhatt, A. 2015. Aerial seed bank affects germination in two small-seeded halophytes in Arab Gulf desert. J. Arid Environ. 117: 10-17. doi:10.1016/j.jaridenv.2015.02.001.

El-Keblawy, A., Al-Ansari, F., and Al Shamsi, N. 2011. Effects of temperature and light on salinity tolerance during germination in two desert glycophytic grasses, Lasiurus scindicus and Panicum turgidum. Grass Forage Sci. 66(2): 173-182. doi:10.1111/ j.1365-2494.2010.00773.x.
El-Keblawy, A., Gairola, S., and Bhatt, A. 2016. Maternal salinity environment affects salt tolerance during germination in Anabasis setifera: a facultative desert halophyte. J. Arid Land, 8(2): 254-263. doi:10.1007/s40333-015-0023-2.

El-Keblawy, A., Gairola, S., and Bhatt, A. 2017. Effects of maternal salinity on salt tolerance during germination of Suaeda aegyptiaca: a facultative halophyte in the Arab Gulf desert. Plant Spec. Biol. 32(1): 45-53. doi:10.1111/1442-1984.12127.

El-Keblawy, A., Al-Shamsi, N, and Mosa, K. 2018. Effect of maternal habitat, temperature and light on germination and salt tolerance of Suaeda vermiculata, a habitat-indifferent halophyte of arid Arabian deserts. Seed Sci. Res. 28(2): 140-147. doi:10.1017/S0960258518000144.

El-Keblawy, A., Soliman, S., Al-Khoury, R., Ghauri, A., Al Rammah, H., Hussain, S.E., et al. 2019. Effect of maturation conditions on light and temperature requirements during seed germination of Citrullus colocynthis from the Arabian Desert. Plant Biol. 21(2): 292-299. doi:10.1111/plb.12923. PMID: 30311346.

Ellis, R.H., and Roberts, E.H. 1981. The quantification of ageing and survival in orthodox seeds. Seed Sci. Technol. 9: 373-409.

Elnaggar, A., El-Keblawy, A., Mosa, K.A., and Navarro, T. 2019. Adaptive drought tolerance during germination of Salsola drummondii seeds from saline and non-saline habitats of the arid Arabian Deserts. Botany, 97(2): 123-133. doi:10.1139/cjb2018-0174.

Fenner, M. 1991a. Effect of parent plant environment on seed size and chemical composition. Hortic. Rev. 13: 183-213.

Fenner, M. 1991b. The effects of the parent environment on seed germinability. Seed Sci. Res. 1: 75-84. doi:10.1017/S0960258500000696.

Fenner, M., and Thompson, K. 2005. The ecology of seeds. Cambridge University Press, Cambridge, UK.

Galloway, L.F. 2001a. Parental environmental effects on life history in the herbaceous plant Campanula americana. Ecology, 82(1): 2781-2789. doi:10.1890/0012-9658(2001)082[2781:PEEOLH]2. $0 . \mathrm{CO} ; 2$.

Galloway, L.F. 2001b. The effect of maternal and paternal environments on seed characters in the herbaceous plant Campanula americana (Campanulaceae). Am. J. Bot. 88(5): 832840. doi:10.2307/2657035. PMID:11353708.

Gulzar, S., and Khan, M.A. 2001. Seed germination of a halophytic grass Aeluropus lagopoides. Ann. Bot. 87(3): 319-324. doi:10.1006/anbo.2000.1336.

Gulzar, S., Khan, M.A., and Ungar, I.A. 2003a. Effects of salinity on growth, ionic content, and plant-water status of Aeluropus lagopoides. Commun. Soil Sci. Plant Anal. 34(11-12): 16571668. doi:10.1081/CSS-120021303.

Gulzar, S., Khan, M.A., and Ungar, I.A. 2003b. Salt tolerance of a coastal salt marsh grass. Commun. Soil Sci. Plant Anal. 34(17-18): 2595-2605. doi:10.1081/CSS-120024787.

Gutterman, Y. 2000. Maternal effects on seeds during development. In Seeds: the ecology of regeneration in plant communities. 2nd ed. Edited by M. Fenner. CAB International, Wallingford, UK. pp. 59-84.

International Seed Testing Association (ISTA). 2003. International rules for seed testing. ISTA, Bassersdorf, Switzerland.

Islam, M.D., Kubo, I., Ohadi, M., and Alili, A.A. 2009. Measurement of solar energy radiation in Abu Dhabi, UAE. Appl. Energy, 86(4): 511-515. doi:10.1016/j.apenergy.2008.07.012.

Khan, M.A., and Gul, B. 1999. Seed bank strategies of coastal populations at Arabian seacoast. In Shrubland ecotones. Edited by E.D. McArthur, W.K. Ostler, and C.L. Wambolt. USDA Forest Service Proceedings RMRS-P-11, Ft. Collins, Colo. pp. 227-230.

Khan, M.A., and Gulzar, S. 2003a. Germination responses of Sporobolus ioclados: a saline desert grass. J. Arid Environ. 53: 387-394. doi:10.1006/jare.2002.1045.

Khan, M.A., and Gulzar, S. 2003b. Light, salinity, and tempera- 


\section{Pagination not final (cite DOI) / Pagination provisoire (citer le DOI)}

ture effects on the seed germination of perennial grasses. Am. J. Bot. 90(1): 131-134. doi:10.3732/ajb.90.1.131. PMID: 21659088.

Khan, M.A., and Ungar, I.A. 1996. Influence of salinity and temperature on the germination of Haloxylon recurvum Bunge ex Boiss. Ann. Bot. 78(5): 547-551. doi:10.1006/anbo.1996.0159.

Kucera, B., Cohn, M.A., and Leubner-Metzger, G. 2005. Plant hormone interactions during seed dormancy release and germination. Seed Sci. Res. 15(4): 281-307. doi:10.1079/ SSR2005218.

Leimu, R., and Fischer, M. 2008. A meta-analysis of local adaptation in plants. PLoS ONE, 3(12): e4010. doi:10.1371/journal. pone.0004010. PMID:19104660.

Migicovsky, Z., Yao, Y., and Kovalchuk, I. 2014. Transgenerational phenotypic and epigenetic changes in response to heat stress in Arabidopsis thaliana. Plant Signal. Behav. 9(2): e27971. doi:10.4161/psb.27971. PMID:24513700.

Mohsenzadeh, S., Malboobi, M.A., Razavi, K., and Farrahi-Aschtiani, S. 2006. Physiological and molecular responses of Aeluropus lagopoides (Poaceae) to water deficit. Environ. Exp. Bot. 56(3): 314-322. doi:10.1016/j.envexpbot.2005.03.008.

Murru, V., Santo, A., Piazza, C., Hugot, L., and Bacchetta, G. 2015. Seed germination, salt-stress tolerance, and the effect of nitrate on three Tyrrhenian coastal species of the Silene mollissima aggregate (Caryophyllaceae). Botany, 93(12): 881-892. doi:10.1139/cjb2015-0148.

Murru, V., Santo, A., Gallo, M., Cardona, C., Boi, M., and Bacchetta, G. 2017. Comparative germination ecology and seedling growth of two Ibero-Levantine endemic species belonging to the Silene mollissima aggregate (Caryophyllaceae). Flora, 227: 10-17. doi:10.1016/j.flora.2016.12.002.

Naz, N., Hameed, M., Ashraf, M., Ahmad, R., and Arshad, M. 2009. Eco-morphic variation for salt tolerance in some grasses from Cholistan Desert, Pakistan. Pak. J. Bot. 41(4): 1707-1714.

Omar, S.A., and Bhat, N.R. 2008. Alteration of the Rhanterium epapposum plant community in Kuwait and restoration measures. Int. J. Environ. Stud. 65(1): 139-155. doi:10.1080/ 00207230701823332.

Paolini, R., Principi, M., Froud-Williams, R.J., Del Puglia, S., and Biancardi, E. 1999. Competition between sugarbeet and Sinapis arvensis and Chenopodium album, as affected by timing of nitrogen fertilization. Weed Res. 39(6): 425-440. doi:10.1046/j. 1365-3180.1999.00156.x.

Phondani, P.C., Bhatt, A., Elsarrag, E., Alhorr, Y.M., and El-Keblawy, A. 2016. Criteria and indicator approach of global sustainability assessment system for sustainable landscaping using native plants in Qatar. Ecol. Indic. 69: 381-389. doi:10. 1016/j.ecolind.2016.05.003.

Podda, L., Santo, A., Leone, C., Mayoral, O., and Bacchetta, G.
2017. Seed germination, salt stress tolerance and seedling growth of Opuntia ficus-indica (Cactaceae), invasive species in the Mediterranean Basin. Flora, 229:50-57. doi:10.1016/j.flora. 2017.02.002.

Pons, T.L. 1992. Seed responses to light. In The ecology of regeneration in plant communities. Edited by $\mathrm{M}$. Fenner. CAB International, Wallingford, UK. pp. 259-284.

R Core Team. 2014. R: a language and environment for statistical computing. [Computer software.] R Foundation for Statistical Computing, Vienna, Austria.

Refka, Z., Ksontini, M., and Ferchichi, A. 2015. Ecology and phenology of Rhus tripartitum (Ucria) grande species situated in arid area in Tunisia. J. Biodivers. Environ. Sci. 7(6): 175-184.

Sambatti, J.B.M., and Rice, K.J. 2006. Local adaptation, patterns of selection, and gene flow in the Californian serpentine sunflower (Helianthus exilis). Evolution, 60(4): 696-710. doi:10.1554/ 05-479.1. PMID:16739452.

Santo, A, Mattana, E., Grillo, O., Sciandrello, S., Peccenini, S., and Bacchetta, G. 2017. Variability on morphological and ecological seed traits of Limonium avei (De Not.) Brullo \& Erben (Plumbaginaceae). Plant Spec. Biol. 32(4): 368-379. doi:10.1111/ 1442-1984.12168.

Stanton-Geddes, J., Shaw, R.G., and Tiffin, P. 2012. Interactions between soil habitat and geographic range location affect plant fitness. PLoS ONE, 7(5): e36015. doi:10.1371/journal.pone. 0036015. PMID:22615745.

Sugahara, V.Y., and Takaki, M. 2004. Effect of light and temperature on seed germination in guava (Psidium guajava L.-Myrtaceae). Seed Sci. Technol. 32(3): 759-764. doi:10.15258/sst.2004.32.3.11.

Weber, D.J. 2009. Adaptive mechanisms of halophytes in desert regions. In Salinity and water stress. Edited by M. Ashraf, M. Ozturk, and H. Athar. Springer, Dordrecht, Netherlands. pp. 179-185. doi:10.1007/978-1-4020-9065-3_18.

Woodell, S.R.J. 1985. Salinity and seed germination patterns in coastal plants. In Ecology of coastal vegetation. Edited by W.G. Beeftink, J. Rozema, and A.H.L. Huiskes. Springer, Dordrecht, Netherlands. pp. 223-229.

Wulff, R.D. 1995. Environmental maternal effects on seed quality and germination. In Seed development and germination. Edited by J. Kigel and G. Galili. Marcel Dekker, New York. pp. 491-506.

Xianzhao, L., Chunzhi, W., and Qing, S. 2013. Screening for salt tolerance in eight halophyte species from Yellow River Delta at the two initial growth stages. ISRN Agron. 2013: 592802. doi:10.1155/2013/592820.

Youssef, A.M. 2009. Salt tolerance mechanisms in some salt tolerant plants from Saudi Arabia and Egypt. Res. J. Agric. Biol. Sci. 5(3): 191-206.

Zuur, A.F., Ieno, E.N., Walker, N.J., Saveliev, A.A., and Smith, G.M. 2009. Mixed effects models and extensions in ecology with R. Springer, New York. 